\title{
Development and Control of an Alkaline Fuel Cell Power Conditioner
}

\author{
T. Rocco, R. M. Duke, S. D. Round \\ Department of Electrical and Computer Engineering \\ University of Canterbury \\ New Zealand
}

\begin{abstract}
This paper presents the development of a prototype $400 \mathrm{~W}$ alkaline fuel cell power conditioner. The power conditioner serves to boost the $4 \mathrm{~V}$ DC produced by the fuel cell into $400 \mathrm{~V} \mathrm{DC}$ suitable for conversion to $230 \mathrm{Vrms} \mathrm{AC}$ to power domestic loads. To compensate for the slow transient behaviour of the fuel cell a power flow buffer, incorporating supercapacitor energy storage has been developed which interfaces directly to the $400 \mathrm{~V}$ DC bus. The result is a modular system where communication between system blocks is minimal and control is achieved by monitoring the $400 \mathrm{~V}$ DC bus. Experimental measurements from the prototype system illustrate the performance of the system during load transient conditions. Several practical design issues of the power electronic converters designed to operate with high voltage transformation ratios are discussed in detail.
\end{abstract}

\section{INTRODUCTION}

A typical monopolar alkaline fuel cell produces low voltage, high current DC [1], [2]. Most domestic applications require a higher voltage AC supply. One function of the power conditioner is to provide this conversion. To avoid irreparable damage to the fuel cell stack, a maximum current ramp rate is specified as approximately $10 \%$ of the maximum rated current per second [3]. In order to supply the AC load without interruption, this stand-alone power conditioner must include some form of short-term stored energy. This energy is used to meet the load demand during an abrupt load increase, while the fuel cell output slowly increases to meet the demand. This stored energy must eventually be replenished by the fuel cell.

A schematic of the power conditioning system satisfying this application is shown in Fig. 1. The system consists of a:

- Fuel cell stack.

- Electrically isolated fuel cell converter to interface stack output power to the DC bus.

- Power flow buffer (PFB), consisting of a supercapacitor bank and discharge/recharge converters, capable of maintaining the DC bus voltage within set limits during load transients when the fuel cell temporarily cannot supply the load. This supercapacitor bank requires recharging when the fuel cell can generate surplus power.

- Unidirectional DC-AC converter to produce sinusoidal $230 \mathrm{Vrms}$ with $5 \%$ voltage accuracy to supply the load.

- $400 \mathrm{~V} \mathrm{DC}$ bus for interconnecting the system blocks to allow efficient power transfer between them.

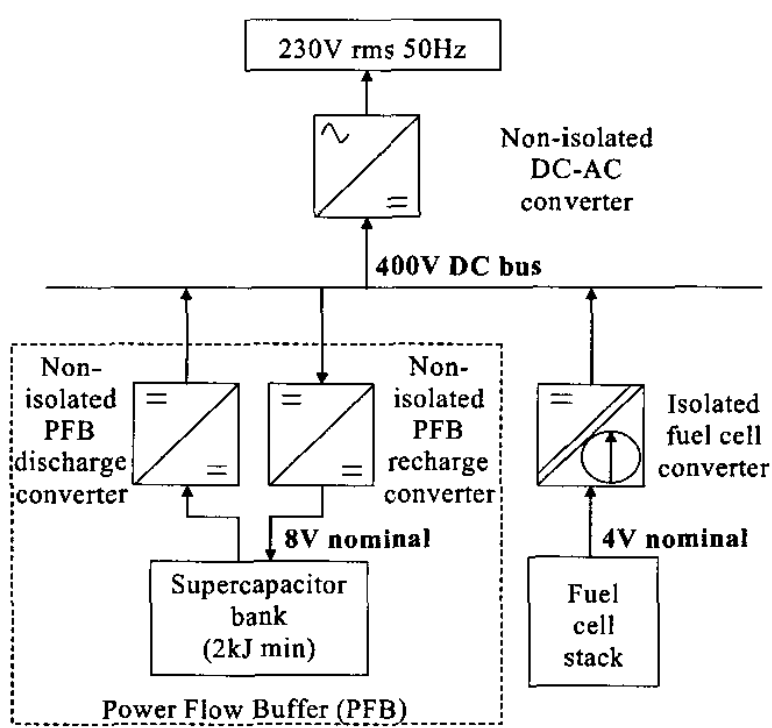

Fig. 1 Fuel cell power conditioning system

This paper presents the design and implementation of this prototype alkaline fuel cell power conditioner system and its associated control.

\section{OPERATING PRINCIPLES}

The $400 \mathrm{~W}$ fuel cell stack used in this prototype operates between 4 and $5.5 \mathrm{~V}$ and can deliver up to $100 \mathrm{~A}$ at full load. The stack can only safely increase its output current at $10 \mathrm{~A}$ per second.

The fuel cell converter must be controlled to deliver power to the $\mathrm{DC}-\mathrm{AC}$ converter when required by the load, while imposing a limit to the current slew rate of the fuel cell of $10 \mathrm{~A}$ per second. The fast-acting PFB must be controlled to compensate for the slow transient response of the fuel cell converter, delivering the balance of power during load transients. Energy extracted from the PFB must be replenished when the fuel cell can generate surplus power. These three functions of the power conditioner are required to be maintained by the control system.

A novel distributed control system is proposed where each of the $\mathrm{DC}-\mathrm{DC}$ converters operates independently according to a set of rules. Using the $400 \mathrm{~V} \mathrm{DC}$ bus as a control parameter eliminates the need for centralised control and associated 
communication within the system. It is worth noting that without the PFB operating; the fuel cell converter cannot maintain a $400 \mathrm{~V}$ DC output during fast load transient conditions, due to the limitation on the fuel cell current slew rate. It is this variation in the DC bus voltage that controls the PFB converters, achieving independent control of all DC-DC converters in the system.

By operating the PFB as a 'voltage clamp' whenever the fuel cell is supplying a deficit or surplus of power, a simple PFB discharge and recharge scheme is achievable. A voltage band of $\pm 5 \%$ of the nominal $400 \mathrm{~V}$ DC bus voltage is chosen to control the PFB converters and allows for expected disturbances on the bus due to voltage ripple and converter over and undershoots.

The proposed operation of this control system is illustrated graphically in Fig. 2. The PFB discharge converter clamps the bus at $380 \mathrm{~V}$ whenever the bus voltage falls due to a deficit in fuel cell power and the PFB recharge converter clamps the $\mathrm{DC}$ bus at $420 \mathrm{~V}$ whenever there is surplus fuel cell power. The fuel cell converter constantly strives to provide exactly $400 \mathrm{~V} \mathrm{DC}$ to the bus, but can only change its input current according to the specified slew rate. As long as the fuel cell converter can maintain the DC bus level within the two set limits of $380 \mathrm{~V}$ and $420 \mathrm{~V}$, the PFB must assume that the load demand is being met within acceptable tolerance and rests in an idle state.
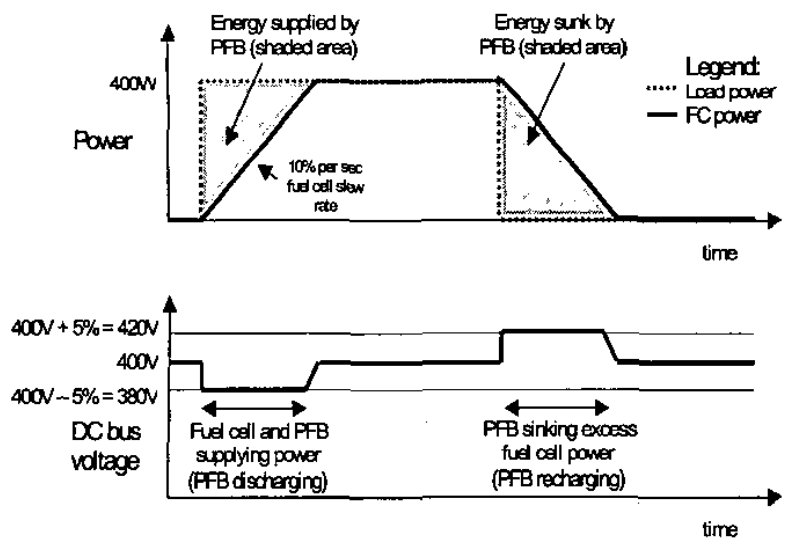

Fig. 2 Idcal operation of proposed control system.

As the PFB may be required to source or sink energy at any given moment, the control system requires the supercapacitor module be partly charged at all times. A supervisory controller monitors the state of charge of the supercapacitor module and initiates a supplementary recharge or discharge from the $400 \mathrm{~V} \mathrm{DC}$ bus to ensure that the state of charge is within set limits. A supplementary recharge or discharge is initiated at a slow rate to allow the fuel cell to adjust to the change without the bus voltage exceeding the allowable $\pm 20 \mathrm{~V}$ from nominal.

\section{PROTOTYPE HARDWARE}

\section{A. Converter Topology}

The fuel cell and PFB discharge converter topologies include a push-pull primary and full bridge rectified secondary, as shown in Fig. 3. This topology accommodates a large transformation ratio while maintaining a high efficiency through the use of a step up transformer. An increase in efficiency over other transformer based DC-DC converters is achieved by having only one switch in series with the supply. This is ideally suited to a low voltage, high current supply such as this $400 \mathrm{~W}$ alkaline fuel cell. At power levels greater than this, other topologies may have greater suitability as described in [4], [5].

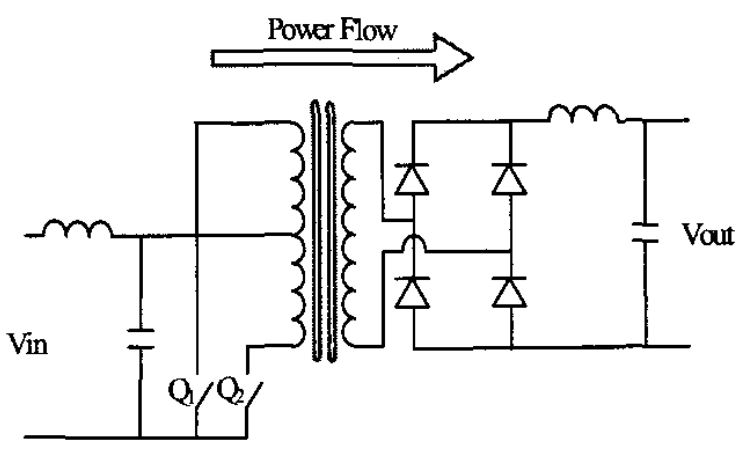

Fig. 3 Push-pull topology

The choice of a single secondary winding over a centretapped secondary winding simplifies transformer construction and provides better utilisation of the winding.

A converter with a full bridge primary and centre- tapped secondary provides the step down function for the PFB recharge converter. This essentially provides the opposite action to the step up converters. The transformer design and busbar layout discussed in sections III.C and III.D is of a similar nature in all the DC-DC converters.

\section{B. Push-pull Converter Control System}

The converter controllers feature an inner pulse-by-pulse current control loop and outer voltage control loop as depicted in Fig. 4. A UC3846 PWM control IC provides the pulse-by-pulse current control, which is necessary to avoid transformer "staircase" saturation [6].

In the fuel cell converter the voltage control loop features a PIC16F877-20 microcontroller in the place of $\mathrm{H}(\mathrm{s})$, which samples the DC bus and provides the current reference to the UC3846. Software ensures the current reference changes at a rate where the fuel cell $\mathrm{di} / \mathrm{dt}$ will be within the specified $10 \mathrm{~A} / \mathrm{sec}$ maximum rate. 
The PFB discharge converter voltage control loop employs an error amplifier and compensator as $H(s)$ to achieve a fast response to changes in $\mathrm{DC}$ bus voltage.

Peak current mode controlled converters such as this require slope compensation [7] for stable. operation above $50 \%$ duty cycle. A $100 \mathrm{mV}$ negative sloping ramp added to the current reference ensures stability at high duty cycles.

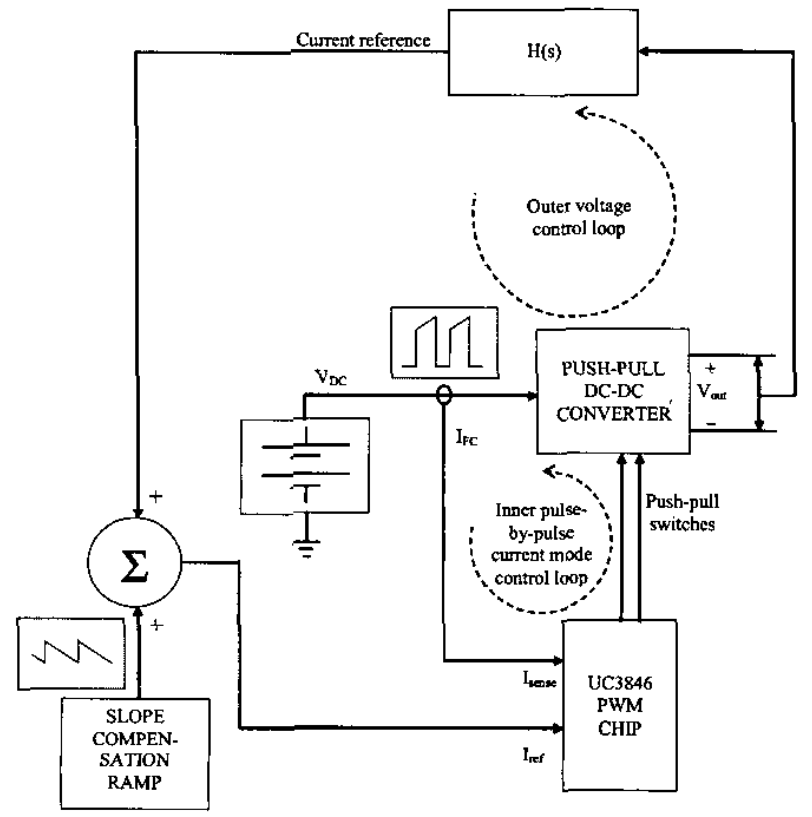

Fig. 4. Push-pull converter control system

\section{Converter Input Hardware}

The push-pull converters employ multiple parallel $60 \mathrm{~V}$ 50A IRFZ44A MOSFET switches, chosen for their low on resistance, to carry the input current. An adverse effect of paralleled devices is the increased drain to source capacitance that can interact with the transformer leakage inductance and cause oscillations, upsetting the pulse-by-pulse current control. These oscillations are further discussed in section IV.A.

The choice of DC bus capacitor type was based on ESR, ripple current rating and cost. 28 parallel $2200 \mu \mathrm{F} 25 \mathrm{~V}$ Rubycon ZL electrolytic capacitors were chosen on these criteria. An advantage of using high performance electrolytic capacitors over film capacitors is the much higher capacitance per unit volume, which simplifies converter input LC filter requirements. As a result of the large DC bus capacitance, sufficient LC filter inductance may be provided by the stray inductance between the fuel cell and the converter. This is simpler and most likely to be more efficient than producing a separate inductor to smooth the DC input current of up to $100 \mathrm{~A}$. A ripple current test in section IV.A shows the fuel cell ripple current to be well within the $1 \%$ specification [3] using this method of filtering.

The minimisation of parasitic inductance in the DC bus capacitance is particularly important for effective operation of the converter. For this reason the DC bus capacitors are mounted on a laminated busbar structure, constructed from $0.6 \mathrm{~mm}$ copper sheet. The through hole capacitors are soldered to the bus in the manner shown in Fig. 5. An indentation in the top lamination allows room for a solder joint within the busbar sandwich.

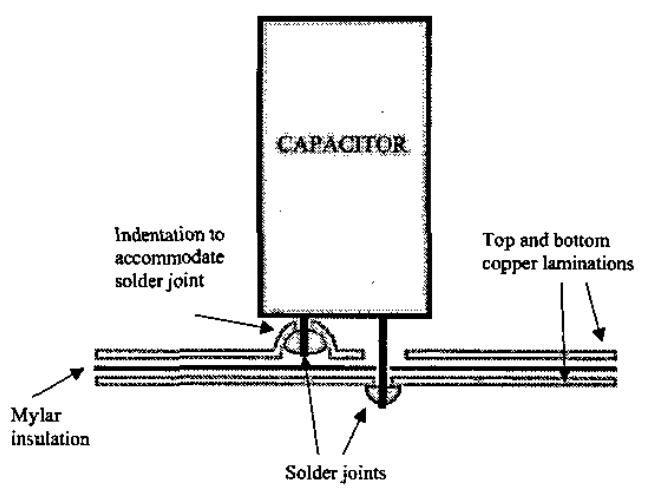

Fig. 5. Cross sectional view of through-hole mount capacitor attached to laminated DC bus

\section{High Frequency Transformer Design}

The most important feature of the converters is the high frequency transformer used to provide the large voltage transformation. An ETD44 core was chosen for the $400 \mathrm{~W}$ transformer, operating at a frequency of $75 \mathrm{kHz}$.

A centre-tapped primary winding, where each half of the primary consists of a single turn, is rated to carry the $100 \mathrm{~A}$ average current supplied by the fuel cell at full load. This was wound using copper foil in order to minimise the leakage inductance by occupying the complete window area with the single turn. Multiple insulated strips of $0.15 \mathrm{~mm}$ thickness copper foil achieve an acceptable current density, while the thin foil ensures that the $\mathrm{AC}$ resistance of the winding due to skin effect is low.

A single secondary winding of 125 turns is wound in two layers underneath the primary ensuring the primary can be terminated easily. A cross section of the winding topology showing the primary terminations is shown in Fig. 6. 


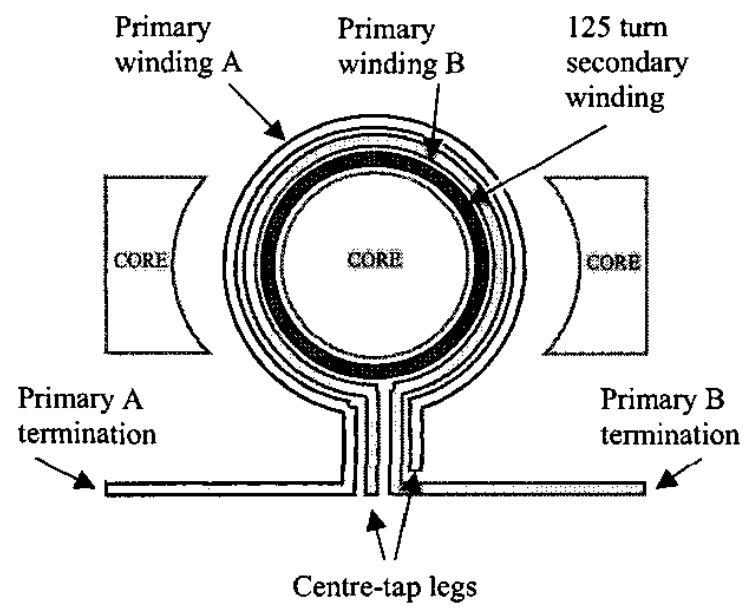

Fig. 6. Cross section of transformer showing centre-tapped foil winding on outermost layers of transformer

\section{EXPERIMENTAL MEASUREMENTS}

\section{A. Fuel Cell Converter Operation}

Waveform (a) of Fig. 7 shows the sensed transformer centre-tap current. The pulses include a $500 \mathrm{kHz}$ oscillation beginning on the rising edge of the pulse due to parasitic elements in the circuit, mentioned in section III.C. As this sensed current is the basis for the pulse-by-pulse current control, the oscillation must be filtered before applying the signal to the UC3846. The filtered signal is shown in waveform (c) of Fig. 7. Waveform (b) shows the current reference provided by the microcontroller including a slope compensation ramp as discussed in section III.B.

The UC3846 compares the filtered transformer centre-tap current signal with the current reference and terminates the PWM pulse when they intersect, thus achieving the desired peak current.

The fuel cell ripple current was measured with the converter drawing 50A DC from the fuel cell. The resulting peak-to-peak ripple current was approximately $80 \mathrm{~mA}$, which is considerably better than the $1 \%$ maximum guideline. As discussed in section III.C, this result is attributed to the large amount of capacitance on the input of the converter. The ripple current waveform is shown in Fig. 8.

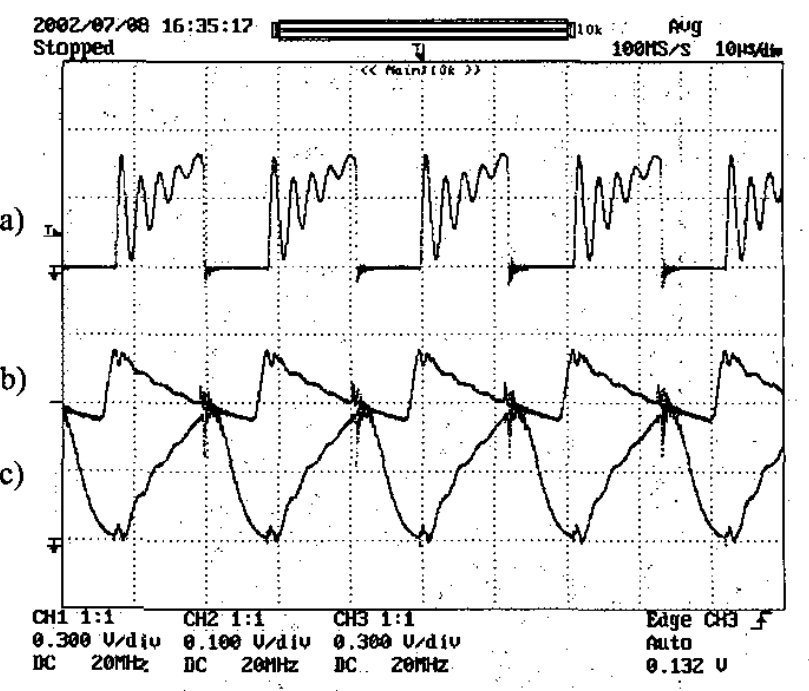

Fig. 7. Fuel cell converter waveforms in order from top to bottom: (a) Unfiltered signal from transformer centretap current sensor (b) Current reference with slope compensation (c) Filtered signal from transformer centretap current

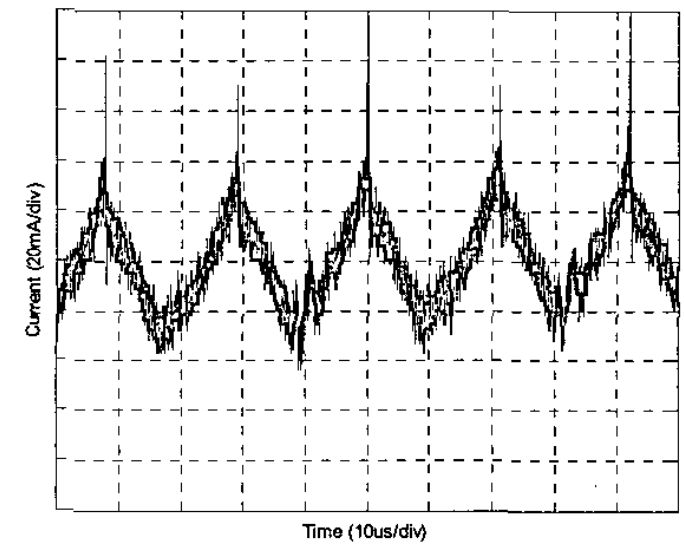

Fig. 8. Fuel cell ripple current measurcment

\section{B. Measured Transient Performance}

Measurements performed during a step load change confirm the desired operation of the system. It can be seen from the test results in Fig. 9 that the PFB responds to the step increase in load at time $t_{1}$ by sensing a fall in the DC bus voltage. From $t_{1}$ to $t_{2}$ the PFB is supplying current to the DC bus to hold the bus level at $380 \mathrm{~V}$ while the fuel cell current ramps up at the specified rate. As the fuel cell current increases, the waveform shows less current being drawn out of the PFB to maintain the $380 \mathrm{~V}$ level. At $t_{2}$ the fuel cell current is high enough to raise the bus above $380 \mathrm{~V}$, so the PFB shuts off completely. The fuel cell is now supplying the 
load independently and continues to ramp up to bring the bus voltage to $400 \mathrm{~V}$. At $t_{3}$ the DC bus reaches $400 \mathrm{~V}$ and the fuel cell begins a repetitive ramp up/ramp down phase, keeping the bus voltage at a nominal $400 \mathrm{~V}$.

(a)

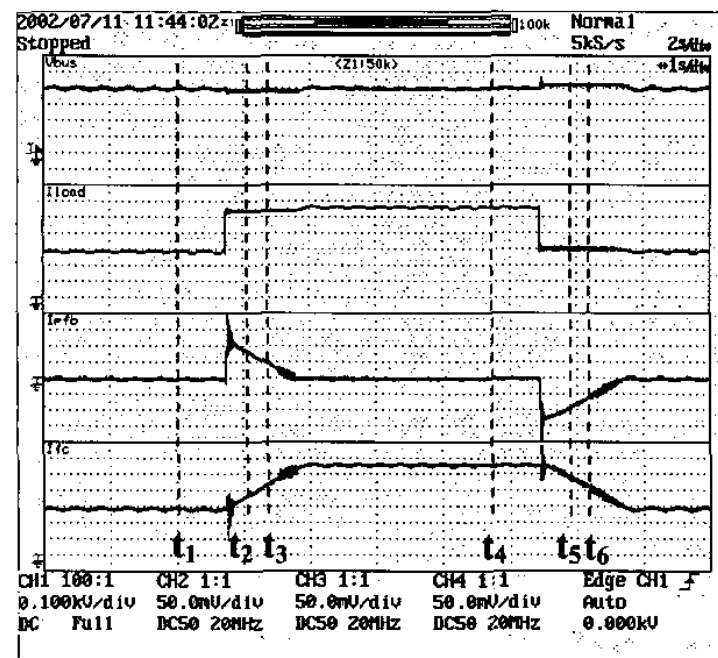

Fig. 9. System behaviour during load transient (a) DC bus voltage (b) Load current (c) Power flow buffer current (d) Fucl cell current

At $t_{4}$ the load suddenly decreases and the fuel cell is providing more current than is required by the load, causing a corresponding rise in the DC bus voltage. The PFB responds to this increased bus voltage and clamps the bus at $420 \mathrm{~V}$ by sinking the excess current, while the fuel cell decreases its output to bring the bus back to $400 \mathrm{~V}$. At $\mathrm{t}_{5}$ the fuel cell current has reduced to a level where the bus voltage is below $420 \mathrm{~V}$ so the PFB shuts off. The fuel cell current continues to ramp down until $400 \mathrm{~V}$ appears on the bus at $t_{6}$ and a repetitive ramp up/ramp down phase begins to maintain the $400 \mathrm{~V}$ level.

This result demonstrates that the load demand can be met and that the PFB can source and sink current as required to keep the DC bus levels within the set limits as the fuel cell slowly adjusts to a step load change.

Fig. 10 shows AC current and voltage waveform envelopes measured during a step load change from $30 \mathrm{~W}$ to $230 \mathrm{~W}$, illustrating the voltage regulation present in the $\mathrm{AC}$ output. This regulation is partly due to the control scheme

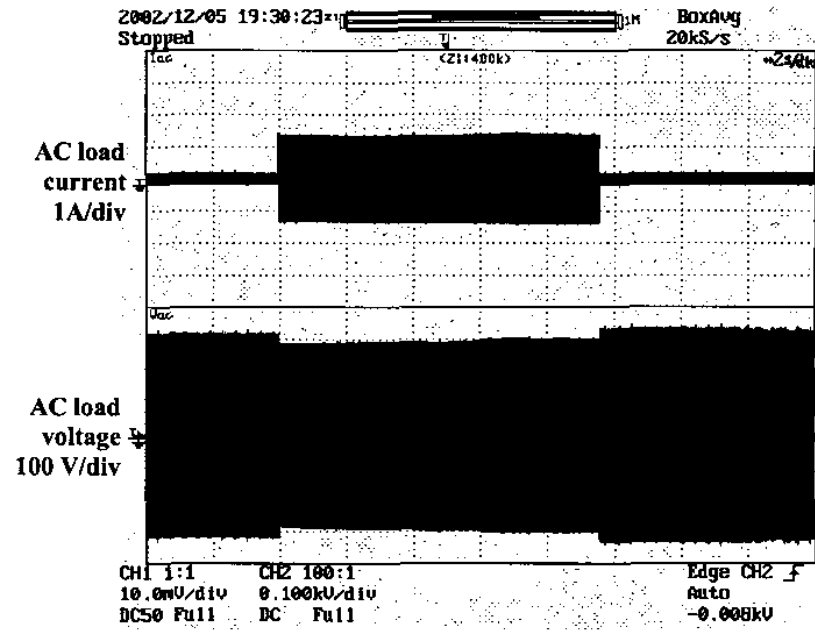

Fig, 10. AC current and voltage measurements during step load change.

Additional regulation is introduced by the current limiting scheme of the DC-AC converter. This mode of current control effectively flat tops the current waveform by limiting the peak current drawn in each PWM. Fig. 11 shows the load current and voltage when the power conditioner, initially supplying a light load, drives an electric drill. This electric drill represents a fairly typical high inertia load. The result shows that when the motor is switched in, the large motor start up current exceeds the peak output current rating of the power conditioner and so forces the DC-AC converter into current limiting. This is evident from the flat-topped current waveform shown in the bottom left close-up window of Fig. 11. After two seconds the motor current reduces to within the power conditioner rating and the flat topped $\mathrm{AC}$ voltage and current waveforms become sinusoidal. The bottom right close-up window of Fig. 11 shows the load current and voltage as the motor switches off and the power conditioner returns to supplying the light load only.

\section{CONCLUSIONS AND FUTURE DEVELOPMENT}

The objectives of this project were to produce a prototype, low cost, modular power conditioning system for a $400 \mathrm{~W}$ alkaline fuel cell where the converter hardware requirements and control implications of such a modular system could be investigated.

A prototype system has been constructed which transforms the $4 \mathrm{~V} \mathrm{DC}$ fuel cell output into $400 \mathrm{~V} \mathrm{DC}$ using a push-pull converter. The 100:1 step up ratio is achieved with a centretapped primary winding consisting of two single turns. The $400 \mathrm{~V} \mathrm{DC}$ output is converted to $230 \mathrm{Vrms} 50 \mathrm{~Hz} \mathrm{AC}$ by a DCAC converter. 
The slow transient behaviour of the fuel cell is compensated by the use of a fast acting PFB, incorporating supercapacitor energy storage. Control of the PFB is achieved by monitoring the $400 \mathrm{~V} \mathrm{DC}$ bus. Tests indicate that a sudden change in load demand can be met by the fast acting PFB, despite the $\mathrm{di} / \mathrm{dt}$ restrictions on the fuel cell.

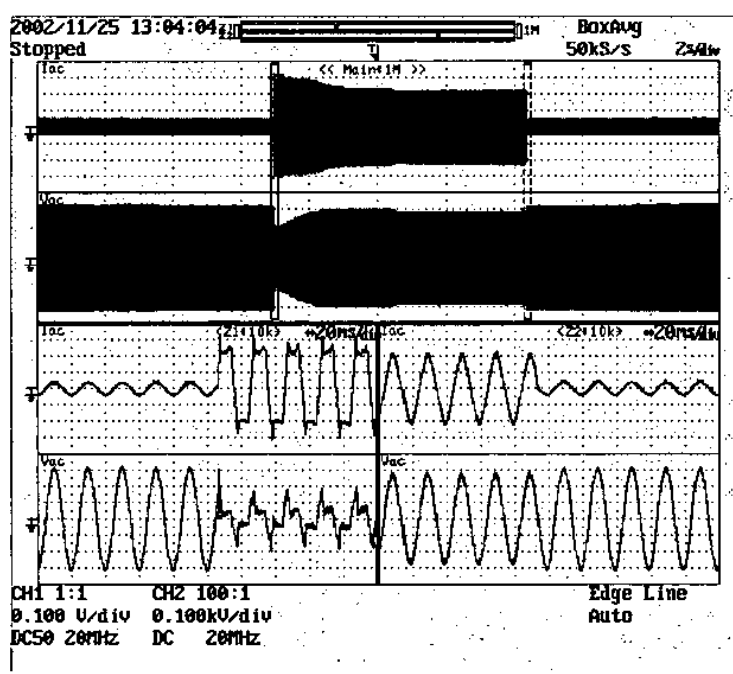

Fig. 11. Electric motor load current and voltage showing lose up of motor start and stop.

\section{ACKNOWLEDGMENTS}

This project has been supported by Industrial Research Limited, Christchurch, New Zealand. The authors would like to acknowledge the support of the Electrotechnology team at IRL and their assistance in supplying much of the hardware used in this prototype system.

\section{REFERENCES}

[1] A. J. Appleby, F. R. Foulkes, Fuel Cell Handbook, Van Nostrand Reinhold, 1989, ISBN 00-442-31926-6, pp 442-445.

[2] K. Kordesch, G. Simader, Fuel Cells and Their Applications, Weinheim, 1996, ISBN 3-527-28579-2, pp 49-50.

[3] ZeTek Power, Technical Specification for the Peripherals for the ZeTek Power Alkaline Fuel Cell System, 2000.

[4] Nergaard, Ferrell, Leslic, Lai, Design Considerations for A 48V Fuel Cell to Split Single Phase Inverter System with Ultracapacitor Energy Storage, Proceedings of the IEEE Power Electronics Specialists Conference PESC, June 23-27 2002, cd-rom.

[5] A. I. Pressman, Switching Power Supply Design, McGraw-Hill, 1992, ISBN 0-07112911-1, pp 63

[6] K. Billings, Switchmode Power Supply Handbook, Second Edition, McGraw-Hill, 1999, ISBN 0-07-006719-8, pp 2.151

[7] Unitrode Corporation, Application Note U-97, Modeling, Analysis and Compensation of the Current-Mode Converter, pp 1-7, 1999. 